\title{
The Length-Weight Characteristics of Five Elasmobranch Species (Pisces: Chondrichthyes) from Izmir Bay (Aegean Sea Coast of Turkey): Spring 2018
}

\author{
Burcu Taylan $^{1, a, *}$, Bahar Bayhan ${ }^{1, b}$, Cemil Sağlam ${ }^{2, c}$, Ali Özcan Babaoğlu ${ }^{3, d}$, Ali Kara ${ }^{3, e}$ \\ ${ }^{1}$ Department of Basic Sciences, Faculty of Fisheries, Ege University, 35100, Bornova/İzmir, Turkey \\ ${ }^{2}$ Fisheries Technology Engineering Department, Fatsa Faculty of Marine Sciences Ordu University, 52200 Ordu, Turkey \\ ${ }^{3}$ Department of Hunting and Processing Technology, Faculty of Fisheries, Ege University, 35100, Bornova/İzmir, Turkey \\ *Corresponding author
}

\begin{tabular}{|c|c|}
\hline A R T I C L E I N F O & A B S T R A C T \\
\hline $\begin{array}{l}\text { Keywords: } \\
\text { Length-weight Relationship } \\
\text { Elasmobranch } \\
\text { Chondrichthyes } \\
\text { Morphometrics }\end{array}$ & $\begin{array}{l}\text { In this study, a total of } 364 \text { samples were collected and } 349 \text { of them belonged to, } 349 \text { specimens of } \\
\text { Dasyatis pastinaca, } 6 \text { of Gymnura altavela, } 5 \text { of Torpedo marmorato, } 2 \text { of Aetomylaeus bovinus } \\
\text { and Mustelus mustelus, were obtained by-catch in trammel nets off the Izmir Bay (Aegean sea coast } \\
\text { of Turkey) during period of spring in } 2018 \text {. Males of } D \text {. pastinaca ranged from } 28-62 \mathrm{~cm} \text { and } \\
\text { females from } 31.5-94 \mathrm{~cm} \text { total length. The analysis of the angular coefficient ( } \mathrm{b} \text { ) demonstrated that } \\
\text { growth (in weight) in relation to length was isometric in males and females of } \text { D. pastinaca. } \\
\text { Morphologic measurements of a total of } 60 \text { individuals to represent all individuals of the population, } \\
\mathrm{t} \text { test in independent groups to determine differences in males and females and all other } \\
\text { morphometric measurements were statistically tested by multiple regression analysis (stepwise } \\
\text { method). Therefore, difference between mean values obtained according to sexes was not found } \\
\text { different. However, A linear correlation between weight- pelvic length for females and weight- } \\
\text { preanal length for males according to multiple regression analysis in male and female individuals. } \\
\text { Isometric and positive allometric growths were calculated for species of Torpedo marmorata and } \\
\text { Gymnura altavela, respectively. }\end{array}$ \\
\hline
\end{tabular}

Skates

Aegean Sea

burcu.taylan@ege.edu.tr csaglam@odu.edu.tr e@ali.kara@ege.edu.tr

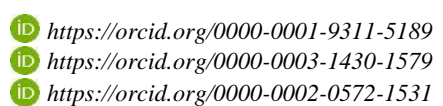

\section{Introduction}

Length weight relationship is a very important data for calculation of growth rates, length and age structures and other constituents of fish population dynamics in fisheries management. Although chondrichthyes species are quite large and the largest predators, they are involved in offtarget fishing (Eronat and Başusta, 2018).

An analysis of threat levels across all sharks, rays and chimaeras has revealed the Mediterranean Sea as a key hotspot of extinction risk (IUCN, 2021). The level of threat may be worse because uncertainty in species status remains moderately high in the Mediterranean Sea; of the 73 assessed species 13 remain Data Deficient. (Dulvy et al., 2016). cartilaginous fish species distributions in Turkey showing $75 \%$ of cartilaginous fish fauna in the Mediterranean sea (Bradaun et al., 2012) are created.

Although their distribution in the Mediterranean is not homogeneous; When the distribution of cartilaginous fish species according to our seas is examined; It is known that there are 64 species in the Levantine Sea and ranks first (Eronat and Bizsel, 2015; Sakalli et al., 2016; Yücel et al., 2017). Number of known species in Levantine Sea is followed by Aegean with 61 species, Marmara Sea with 36 species and Blacksea with 9 species respectively (Bilecenoglu et al., 2014).

The number of species distributed in Turkish and World seas observed during the research, which are members of Dasyatidae (Dasyatis pastinaca), Torpedinidae, (Torpedo marmorata), Gymnuridae (Gymnura altavela), Myliobatidae (Aetomylaeus bovinus), Triakidae (Mustelus mustelus) families, are 7-99; 1-24; 316; 4-19; 4-46 respectively (Froese and Pauly, 2020; Bilecenoğlu et al., 2014). 3 of the 5 species (Dasyatis pastinaca, Gymnura altavela and Mustelus mustelus) observed during research are vulnerable (VU), the other 2 species (Torpedo marmorata and Aetomylaeus bovinus) are data deficient (DD) in red list category (IUCN, 2020). 
Since Elasmobranchii species have a K-selected (long life) life cycle, they show low growth rate and low resistance to fishery operation death (Hoenig and Gruber, 1990; Frisk et al., 2001). In commercial fisheries, liabilities, restrictions and prohibitions related to fish capture have been regulated to protect current fisheries sources and provide their sustainable management. For the purpose involved, Regulation of Commercial Fisheries on the notification amendment $(2016 / 35)$ for the amendment of the notification no 4/1 by Ministry of Agriculture and Forestry Republic of Turkey was published in the Official Gazette and validated in 2018. Sharks and Manta rays are included in the group of fisheries' species which are commercially forbidden to catch.

Studies on Cartilaginous species across Turkish seas belong to Demirhan et al. (2005) and Demirhan and Seyhan (2007) in Black Sea, Bök et al., 2011) in Marmara Sea, Işmen (2003), Yeldan and Avşar (2007), Yeldan et al. (2008), Yeldan et al. (2009), Duman and Başusta (2013), Girgin and Başusta (2016), Guven et al. (2011) in the Mediterranean sea, Filiz and Mater (2002) and Eronat and Özaydın (2014) in Aegean sea.

The length-weight parameters of the same species may be different in the population because of feeding, reproduction activities and fishing etc. Therefore, we need to know length-weight relationships of fish species which are captured in a given place in a certain period of time (Bayhan et al., 2008, Gurkan et al., 2010). The study conducted for this purpose established length-weight relationships of three elasmobranch species inhabiting Izmir Bay in Aegean Sea of Turkey in 2018.

\section{Material and Methods}

The present study examined 364 individuals of 5 cartilaginous species (Dayatis pastinaca, Torpedo marmorata, Gymnura altavela, Aetomylaeus bovinus and Mustelus mustelus) captured as discards using trammel nets on the boats in İzmir Bay, Aegean sea during period of Spring in 2018. Total length (TL, cm) and weight (W; $0.01 \mathrm{~g}$ ) of the fishes brought to the laboratory were measured, respectively. In order to determine relationship between length and weight, $\mathrm{W}=\mathrm{a} \times \mathrm{L}^{\mathrm{b}}$ was used, where $\mathrm{W}$ is total fish weight, L total length, $a$ its condition factor coefficient and $b$ its width (Ricker, 1975). $\mathrm{b}=3$ means that growth is isometric, $b<3$ that growth is of negative allometry and $b>3$ that growth has positive allometry (Karachle and Stergiou, 2012). 8 morphometric characters were measured in a total of 60 samples to represent all individuals of $D$. pastinica population and obtained mean values were statistically tested by t-test and morphometric characters by stepwise method in multiple regression analysis with weight being dependent variable. Statistical calculations were tested with an meaning level of $\mathrm{P}<0.05$ using IBM SPSS 25.0.

\section{Results}

The study examined a total of 365 cartilaginous species of fish with 349 Dayatis pastinaca, 7 Gymnura altavela, 2 Aetomylaeus bovinus, 2 Mustelus mustelus and 5 Torpedo marmorata.

All examined individuals of Dasyatis pastinaca showed length group values of $28-94 \mathrm{~cm}$ with $35-44.5 \mathrm{~cm}$ length range by $68.5 \%$ ranking as the first, followed by 45 $54.9 \mathrm{~cm}$ by $17.8 \%$. Mean total length and weight values of the species were $42.5 \pm 0.44 \mathrm{~cm}$ and $385.26 \pm 20.79 \mathrm{~g}$, respectively. Total length- weight relationship was found $\mathrm{W}=0.0022 \mathrm{~L}^{3.18}\left(\mathrm{r}^{2}=0.995\right)$ with a positive allometric growth (Table 1).

5 individuals of Torpedo marmorata species exhibited minimum maximum length range of $20.5-29.5 \mathrm{~cm}$ Its mean total length and weight values were $23.9 \pm 1.53 \mathrm{~cm}$ and $293 \pm 68.81 \mathrm{~g}$, respectively. Total length and weight relationship was $\mathrm{W}=0.0108^{3.20}\left(\mathrm{r}^{2}=0.969\right)$ with an isometric growth (Table 1).

7 individuals of Gymnura altavela had a minimum maximum length range of $31.5-68 \mathrm{~cm}$. Its mean total length and weight values were $43.73 \pm 5.36 \mathrm{~cm}$ and $2699.83 \pm 1035.29 \mathrm{~g}$, respectively. Total length weight relationship was $\mathrm{W}=0.9109 \mathrm{~L}^{3.22}\left(\mathrm{r}^{2} 0.861\right)$ with a positive allometric growth (Table 1).

However, with less than 5 individuals Aetomylaeus bovinus and Mustelus mustelus showed minimum, maximum and mean total length and weight values. As a result, Aetomylaeus bovinus ( 2 individuals) had mean total length and weight of $128 \pm 52.16 \mathrm{~cm}$ and $6960 \pm 6058.05 \mathrm{~g}$, respectively. 2 individuals of Mustelus mustelus showed mean total length and weight of $87.9 \pm 3.11 \mathrm{~cm}$ and 2201.8 $\pm 173.79 \mathrm{~g}$ (Table 2 ), respectively.

Table 1. Length-weight relationships of 3 elasmobranch species by-catch in trammel nets off the Izmir Bay

\begin{tabular}{|c|c|c|c|c|c|c|c|c|c|c|}
\hline \multirow[b]{2}{*}{$\mathrm{N}$} & \multicolumn{2}{|c|}{$\mathrm{LC}$} & \multicolumn{2}{|r|}{$\mathrm{WC}$} & \multicolumn{6}{|c|}{ Relationship Parameters } \\
\hline & $\begin{array}{l}\text { TL Range } \\
(\mathrm{cm})\end{array}$ & $\begin{array}{c}\text { Mean TL } \\
( \pm \text { SE })\end{array}$ & $\begin{array}{l}\text { W Range } \\
(\mathrm{g})\end{array}$ & $\begin{array}{c}\text { Mean W } \\
( \pm \text { SE })\end{array}$ & $a$ & $b$ & $\mathrm{SE}$ of $b$ & $\begin{array}{c}95 \% \mathrm{Cl} \text { of } \\
b\end{array}$ & $r^{2}$ & $\mathrm{R}$ \\
\hline \multicolumn{11}{|c|}{ Torpenidae $^{1}\left(3 q+2 \bigcirc^{1}\right)$} \\
\hline 5 & $20.5-29.5$ & $23.9 \pm 1.53$ & $185-560$ & $293 \pm 68.81$ & 0.0108 & 3.195 & 0.330 & $2.535-3.855$ & 0.969 & IS \\
\hline \multicolumn{11}{|c|}{ Dasyatidae $^{2}(\Sigma)$} \\
\hline 349 & $28-94$ & $42.5 \pm 0.44$ & $85-4985$ & $385.2 \pm 20.79$ & 0.0022 & 3.179 & 0.015 & $3.149-3.205$ & 0.995 & $\mathrm{AL}$ \\
\hline \multicolumn{11}{|c|}{ Dasyatidae $^{3}(+)$} \\
\hline 172 & $31.5-94$ & $42.62 \pm 0.66$ & $153.4-4985$ & $404.59 \pm 35.56$ & 0.0017 & 3.245 & 0.167 & $2.911-3.579$ & 0.688 & IS \\
\hline \multicolumn{11}{|c|}{ Dasyatidae $^{4}\left({ }^{1}\right)$} \\
\hline 152 & $28-62$ & $41.2 \pm 0.09$ & $85-1095$ & $314.9 \pm 14.78$ & 0.0040 & 3.009 & 0.100 & $2.809-3.209$ & 0.865 & IS \\
\hline \multicolumn{11}{|c|}{ Gymnuridae $^{5}\left(3++3 \bigcirc^{1}\right)$} \\
\hline 6 & $31.5-68$ & $43.73 \pm 5.36$ & $670-6920$ & $2699.83 \pm 1035.29$ & 0.0109 & 3.215 & 0.053 & $3.109-3.321$ & 0.861 & $\mathrm{AL}$ \\
\hline
\end{tabular}


Table 2. Descriptive statistics for Mustelus mustelus and Aetomylaeus bovinus caught in in trammel nets off the Izmir Bay (Aegean Sea Coast of Turkey)

\begin{tabular}{l|cccccc}
\hline Familia/Species & Sex & N & TL(cm) Min.-Max. & TL(cm) Mean \pm SE & TW(g) Min.-Max. & TW (g) Mean \pm SE \\
\hline Triakidae $^{1}$ & 0 & 2 & $84.8-91$ & $87.9 \pm 3.11$ & $2025.5-2378.1$ & $2201.8 \pm 173.79$ \\
Myliobatidae $^{2}$ & + & 2 & $76-180$ & $128 \pm 52.16$ & $920-13000$ & $6960 \pm 6058.05$ \\
\hline
\end{tabular}

Table 3 Morphometric measurement values of Dasyatis pastinaca caught in in trammel nets off the Izmir Bay (Aegean Sea Coast of Turkey)

\begin{tabular}{l|cccc}
\hline \multirow{2}{*}{ Measurements } & \multicolumn{2}{c}{$\bar{\partial}(29)$} & \multicolumn{2}{c}{ M (31) } \\
\cline { 2 - 5 } & Min.-Max. & Mean \pm SE & Mean \pm SE \\
\hline TL (cm) & $29.5-76$ & $42.11 \pm 1.71$ & $34.5-94$ & $45.42 \pm 2.35$ \\
Width of Disc (cm) & $17.4-38.45$ & $21.89 \pm 0.88$ & $18-47.6$ & $23.66 \pm 1.14$ \\
TW (g) & $110-2075$ & $388.45 \pm 75.68$ & $200-4985$ & $599.03 \pm 163.12$ \\
Preanal Length (cm) & $13-32$ & $17.14 \pm 0.78$ & $14.1-41$ & $18.95 \pm 1.04$ \\
Prepelvic Length (cm) & $12.5-30.5$ & $16.18 \pm 0.811$ & $13.3-40$ & $18.29 \pm 1.00$ \\
Prepectoral Length (cm) & $10.5-23.5$ & $13.76 \pm 0.58$ & $11.6-30$ & $14.63 \pm 0.76$ \\
Body Height (cm) & $2.1-7$ & $3.25 \pm 0.18$ & $2-10$ & $3.54 \pm 0.31$ \\
Head Length (cm) & $7.3-17$ & $9.61 \pm 0.41$ & $8-21$ & $10.35 \pm 0.51$ \\
Eye Diameter (cm) & $1.2-1.8$ & $1.43 \pm 0.03$ & $1.2-2.1$ & $1.53 \pm 0.04$ \\
Preorbital Length (cm) & $3.2-6.5$ & $3.91 \pm 0.17$ & $3.7-8.5$ & $4.20 \pm 0.23$ \\
\hline
\end{tabular}

8 characters of 60 samples of D.pastinaca to represent all its individuals were measured ( Table 3 ). All the mean values were statistically tested.

In conclusion, significance test between two mean values from morphometric measurements of sexes did not show any differences. On the other hand, for females by multiple regression analysis, $\mathrm{W}=-2195.7 \pm 152.825$ prepelvic length in males, a linear relationship was obtained between weight and preanal length as $\mathrm{W}=$ $1244.04 \pm 94.511$ preanal length.

\section{Discussion}

The species examined in the study were those captured by trammel nets of the boats in İzmir Bay. Therefore, numbers of individuals of some species are quite low.

Studies previously made on length- weight relationship for 5 species examined in the present study are shown in Table 4. Considering those perfomed on the species Dasyatis pastinaca in previous years, value $b$ are usually greater than 3 implying that it is positive allometric which is similar to the present study (Table 2) whereas value $b$ is generally of negative allometry in the species Torpedo marmorata, which is different from our study (Table 2). As for the studies on Gymnura altavela, Filiz and Bilge (2004) and Ozaydin et al. (2007) found $b<3$ to show that the species is of negative allometry while Yeldan and Avşar (2007), Ilkyaz et al. (2008) and the present study found that b $>3$ to show a positive allometric value (Table 2).

Regarding Mustelus mustelus, studies in North Aegean sea (Filiz and Bilge, 2004), Saros Bay (Ismen et al., 2007), Central Aegean sea (Ilkyaz et al., 2008) showed b with positive allometry whereas those in İzmir Bay (Ozaydın et al., 2007) and in Saroz Bay (Ismen et al., 2009) found $b$ with negative allometry.

A study on Aetomylaeus bovinus by Başusta and Aslan (2018) in Norheast Mediterranean sea presented a lengthweight relationship as $\mathrm{W}=0.05815 \times \mathrm{DW}^{2.94}$. However, our study failed to calculate length-weight relationship just because the species was represented with 2 individuals.

The LWR parameters $(a, b)$ of the fish are affected by a series of factors such as season, habitat, gonad maturity, sex, diet, stomach fullness, health, preservation techniques and annual differences in environmental conditions (Bagenal and Tesch, 1978). Such differences in values $b$ can be ascribed to one or a combination of most of the factors including differences in the number of specimens examined, area/season effects and distinctions in the observed length ranges of the specimens caught, to which duration of sample collection can be added as well (Moutopoulos and Stergiou, 2002).

According to Dulvy et al. (2016), despite our rapidly improved understanding of Chondrichthyans widespread overexploitation in the Mediterranean basin, no effective chondrichthyan-focused management measures have been successfully implemented, nor enforced. Stock assessments are underway, however assessments are not management measures, but essential precursors to set catch limits for those more productive species that could be brought into sustainability.

The present study in which data of length and weight frequence distribution were assesssed for 5 cartilaginous species across bay of İzmir in Spring 20183 of which are included in vulnerable category by IUCN is expected to be of great contribution to fisheries management studies in future. 
Table 4. Length-weight relationship parameters of Chondrichthyes fish species obtained by other authors from coasts of Turkey

\begin{tabular}{|c|c|c|c|c|c|c|c|c|c|}
\hline Sex & LT & $\mathrm{SR}(\mathrm{cm})$ & WR (g) & $\mathrm{N}$ & $\mathrm{a}$ & $\mathrm{b}$ & $\mathrm{r}^{2}$ & Area & $\bar{A}$ \\
\hline \multicolumn{10}{|c|}{ Dasyatis pastinaca } \\
\hline$\sum$ & TL & $40.0-74.20$ & $387.83-2955.00$ & 14 & 0.0085 & 2.938 & 0.969 & & \\
\hline $\overrightarrow{0}$ & $\mathrm{TL}$ & $40.0-74.20$ & $387.83-2955.00$ & 8 & 0.0092 & 2.933 & 0.978 & AR1 & 1 \\
\hline q & $\mathrm{TL}$ & $40.30-68.0$ & $392.42-1750.00$ & 6 & 0.0108 & 2.857 & 0.980 & & \\
\hline$\sum$ & $\mathrm{TL}$ & $20.0-88.0$ & - & 256 & 0.0014 & 3.310 & 0.940 & & \\
\hline$\vec{\sigma}$ & $\mathrm{TL}$ & $20.0-73.0$ & - & 146 & 0.00237 & 3.17 & 0.95 & AR2 & 2 \\
\hline q & $\mathrm{TL}$ & $20.5-88.0$ & - & 110 & 0.00091 & 3.44 & 0.94 & & \\
\hline$\sum$ & TL & $23.5-40.61$ & $128.0-401.8 .0$ & 10 & 0.1306 & 2.170 & 0.865 & AR3 & 3 \\
\hline$\sum$ & $\mathrm{TL}$ & $37.3-74.2$ & $333.23-2955.0$ & 29 & 0.0149 & 2.810 & 0.850 & AR1 & 4 \\
\hline$*$ & $\mathrm{TL}$ & $29.2-37.8$ & $*$ & 12 & 0.1168 & 2.122 & 0.642 & AR1 & 5 \\
\hline$\Sigma$ & DW & $20.5-66.0$ & $282.0-14602.0$ & 48 & 0.0126 & 3.302 & 0.990 & AR4 & 6 \\
\hline$*$ & TL & $44.2-138.0$ & $*$ & 16 & 0.0023 & 3.248 & 0.986 & AR5 & 7 \\
\hline$\sum$ & $\mathrm{TL}$ & $23.4-109.9$ & $22.5-6800.1$ & 334 & 0.0020 & 3.242 & 0.970 & & \\
\hline $\overrightarrow{0}$ & $\mathrm{TL}$ & 23.4-69.5 & $22.5-2950.2$ & 145 & 0.0014 & 3.338 & 0.95 & AR1 & 8 \\
\hline q & $\mathrm{TL}$ & 29.0-100.9 & 45.3-6800.1 & 189 & 0.0025 & 3.186 & 0.97 & & \\
\hline$\sum$ & DW & $19.0-43.2$ & $*$ & 31 & 0.0102 & 3.370 & 0.984 & AR6 & 9 \\
\hline$\sum$ & $\mathrm{TL}$ & $37.5-114.0$ & $282.40-16560$ & 71 & 0.0007 & 3.550 & 0.957 & & \\
\hline $\overrightarrow{0}$ & $\mathrm{TL}$ & $40.0-110.0$ & $440.0-16560.0$ & 26 & 0.0005 & 3.64 & 0.951 & AR4 & 10 \\
\hline 오 & $\mathrm{TL}$ & $37.5-114.0$ & 282.4-14750.0 & 45 & 0.0008 & 3.54 & 0.956 & & \\
\hline$\sum$ & $\mathrm{TL}$ & $14.60-100.9$ & $22.5-6800.0$ & 346 & 0.0033 & 3.1429 & $*$ & AR1 & 11 \\
\hline$\sum$ & $\mathrm{TL}$ & $33.4-138.0$ & $191.38-21100$ & 78 & 0.0011 & 3.460 & 0.968 & & \\
\hline $\overrightarrow{0}$ & $\mathrm{TL}$ & $36.5-80.0$ & $295.14-4000$ & 36 & 0.0021 & 3.29 & 0.954 & AR6 & 12 \\
\hline q & TL & 33.4-138.0 & $191.38-21100$ & 42 & 0.9713 & 3.51 & 0.971 & & \\
\hline$\sum$ & DW & $16.60-69.30$ & $94.0-10564.0$ & 384 & 0.0252 & 3.080 & 0.972 & AR7 & 13 \\
\hline o & $\mathrm{TL}$ & $31.5-94.0$ & $153.4-4985.0$ & 172 & 0.0017 & 3.245 & 0.688 & AR5 & 14 \\
\hline$\hat{\sigma}$ & $\mathrm{TL}$ & $28.0-62.0$ & $85.0-1095.0$ & 152 & 0.0040 & 3.009 & 0.865 & AR5 & 15 \\
\hline$\sum$ & $\mathrm{TL}$ & $28.0-94.0$ & $85.0-4985.0$ & 349 & 0.0022 & 3.179 & 0.995 & AR5 & 16 \\
\hline \multicolumn{10}{|c|}{ Torpedo marmorata } \\
\hline$\sum$ & TL & $9.6-25.0$ & $23.51-340.0$ & 20 & 0.0488 & 2.6935 & 0.9584 & & \\
\hline$\vec{\sigma}$ & $\mathrm{TL}$ & $9.6-20.5$ & $23.51-156.94$ & 9 & 0.1191 & 2.3461 & 0.9295 & AR1 & 17 \\
\hline 우 & $\mathrm{TL}$ & $11.0-25.0$ & $27.15-340.0$ & 11 & 0.0274 & 2.9227 & 0.9933 & & \\
\hline$\sum$ & TL & $21.0-38.0$ & $225.0-1275.1$ & 9 & 0.1297 & 2.467 & 0.802 & AR3 & 18 \\
\hline$\sum$ & $\mathrm{TL}$ & $9.2-34$ & $14.88-862.11$ & 37 & 0.0273 & 2.910 & 0.980 & AR1 & 19 \\
\hline$\sum$ & $\mathrm{TL}$ & $16.4-38.9$ & $*$ & 22 & 0.0139 & 3.103 & 0.952 & AR1 & 20 \\
\hline$\sum$ & TL & $13.2-28.6$ & $52.0-450.0$ & 20 & 0.0592 & 2.643 & 0.987 & AR4 & 21 \\
\hline$\sum$ & TL & $10.3-37$ & $*$ & 12 & 0.0535 & 2.639 & 0.981 & AR5 & 22 \\
\hline$\sum$ & $\mathrm{TL}$ & $9.9-42$ & $*$ & 35 & 0.0232 & 2.980 & 0.990 & AR6 & 23 \\
\hline$\sum$ & $\mathrm{TL}$ & $9.3-40$ & $16.0-1308.0$ & 117 & 0.0195 & 2.986 & 0.926 & & \\
\hline $\overrightarrow{0}$ & TL & $9.3-30.3$ & $16.0-474.0$ & 56 & 0.0315 & 2.817 & 0.921 & AR7 & 24 \\
\hline q & $\mathrm{TL}$ & $15.2-40$ & 56.0-1308.0 & 61 & 0.017 & 3.039 & 0.922 & & \\
\hline$\sum$ & $\mathrm{TL}$ & $9.6-39.3$ & $7.98-1310.42$ & 107 & 0.0230 & 2.960 & 0.939 & & \\
\hline $\overrightarrow{0}$ & $\mathrm{TL}$ & $10.0-27.9$ & $24.57-413.29$ & 48 & 0.0365 & 2.79 & 0.985 & AR6 & 26 \\
\hline 운 & TL & $9.6-39.3$ & $7.98-1310.42$ & 59 & 0.0188 & 3.02 & 0.985 & & \\
\hline $3 q+20^{\pi}$ & $\mathrm{TL}$ & $20.5-29.5$ & $185.0-560.0$ & 5 & 0.0108 & 3.195 & 0.969 & AR5 & 26 \\
\hline \multicolumn{10}{|c|}{ Gymnura altavela } \\
\hline$\sum$ & TL & $37.5-72$ & $1188.0-9000$ & 9 & 0.0268 & 2.960 & 0.980 & AR1 & 27 \\
\hline$\sum$ & $\mathrm{TL}$ & $37.6-95$ & $*$ & 17 & 0.0449 & 2.840 & 0.986 & AR5 & 28 \\
\hline$\sum$ & TL & $30.2-83.5$ & $360.5-2400.1$ & 107 & 0.0090 & 3.234 & 0.980 & & \\
\hline $\overrightarrow{0}$ & $\mathrm{TL}$ & $30.7-83.5$ & $360.5-2400.1$ & 38 & 0.0057 & 3.358 & 0.970 & AR8 & 29 \\
\hline q & $\mathrm{TL}$ & $30.2-79.8$ & $450.1-1500.0$ & 69 & 0.0011 & 3.208 & 0970 & & \\
\hline$\sum$ & DW & $47.1-88.3$ & $*$ & 9 & 0.0025 & 3.270 & 0.970 & AR6 & 30 \\
\hline $3 q+3 \jmath^{\pi}$ & $\mathrm{TL}$ & $31.5-68$ & 670.0-6920 & & 0.0053 & 3.215 & 0.861 & AR5 & 31 \\
\hline
\end{tabular}

LT: Length type, SR: Size range, WR: Weight range,

A: Author(1: Filiz and Mater, 2002, 2: Ismen, 2003, 3: Turker et al., 2019, 4: Filiz and Bilge, 2004, 5: Karakulak et al., 2006, 6: Ismen et al., $2007,7$. Ozaydin et al., 2007, 8: Yeldan and Avsar, 2007, 9: Ilkyaz et al., 2008,), 10: Yiğin and Ismen, 2009, 11: Yeldan et al., 2009, 12: Eronat and Özaydın, 2014, 13: Girgin and Başusta, 2016, 14: Present study, 15: Present study, 16: Present study, 17: Filiz and Mater, 2002, 18: Turker at al., 2019, 19: Filiz and Bilge, 2004, 20: Karakulak et al., 2006, 21: Ismen et al., 2007, 22: Ozaydin et al., 2007, 23: Ilkyaz et al., 2008, 24: Duman and Başusta, 2013, 25: Eronat and Özaydin, 2014, 26: This study, 27: Filiz and Bilge, 2004, 28: Ozaydin et al., 2007, 29: Yeldan and Avsar, 2007, 30: Ilkyaz et al., 2008, 31: This study

Area (AR1: North Aegean Sea, AR2: North east Mediterranean, AR3: Edremit Bay, AR4: Saros Bay, AR5: Izmir Bay, AR6: Central Aegean Sea, AR7: Iskenderun Bay, AR8: Northeastern Mediterranean),

*: unidentified sex; TL: Total Length; DW: Disc Width; N: Sample size; a and b: Intercept and Slope of Length-Weight Relationships; ${ }^{2}$, Coefficient of Determination 


\section{References}

Bagenal TB, Tesch FW. 1978. Age and Growth. In: Bagenal, T., Ed., Methods for Assessment of Fish Production in Fresh Waters, 3rd Edition, IBP Handbook No. 3, Blackwell Science Publications, Oxford.

Başusta N, Aslan E. 2018. Age and growth of bull ray Aetomylaeus bovinus (Chondrichthyes: Myliobatidae) from the northeastern Mediterranean coast of Turkey. Cahiers deBiologie Marine, 59: 107-114.

Bayhan B, Sever TM, Taşkavak E. 2008. Length-weight Relationships of Seven Flatfishes (Pisces: Pleuronectiformes) from Aegean Sea. Turkish Journal of Fisheries and Aquatic Sciences, 8: 377-379.

Bilecenoglu M, Kaya M, Cihangir B, Cicek, E. 2014. An Updated Checklist of The Marine Fishes of Turkey. Turkish Journal of Zoology, 38. doi:10.3906/zoo-1405-60.

Bök TD, Gokturk D, Kahraman AE, Alicli TZ. 2011. LengthWeight Relationships of 34 Fish Species From The Sea of Marmara, Turkey. Journal of Animal and Veterinary Advances, 10(23): 3037-3042.

Bradaun MN, Saidi B, Enajjar S. 2012. Elasmobranchs of the Mediterranean and Black sea: status, ecology and biology. Bibliographic analysis. Studies and Reviews. General Fisheries Commission for the Mediterranean, No. 91. Rome, FAO. 103 pp.

Demirhan SA, Engin S, Seyhan K, Akamca E. 2005. Some Biological Aspects of Thornback Ray (Raja clavata L., 1758) in the Southeastern Black Sea. Turkish Journal of Fisheries and Aquatic Sciences, , 5: 75-83.

Demirhan SA, Seyhan K. 2007. Life history of spiny dogfish, Squalus acanthias (L. 1758), in the southern Black Sea. Fisheries Research, 85(1-2), 210-216. https://dx.doi.org/10.1016/j.fishres.2007.02.009

Dulvy N, Allen D, Ralph G, Walls R. 2016. The conversation status of Sharks, Rays and Chimaeras in the Mediterranean Sea. International Union for Conservation of Nature, IUCN Centre for Mediterranean Cooperation, DOI: 10.13140/RG.2.2.22020.53129.

Duman ÖV, Başusta N. 2013. Age and Growth Characteristics of Marbled Electric Ray Torpedo marmorata (Risso, 1810) Inhabiting Iskenderun Bay, North-eastern Mediterranean Sea. Turkish Journal of Fisheries and Aquatic Sciences, 13(3): 541-549.

Eronat, E. G. T., \& Özaydın, O. (2014). Length-weight relationship of cartilaginous fish species from Central Aegean Sea (Izmir Bay and Siğacık Bay). Ege Journal of Fisheries and Aquatic Sciences, 31(3): 119-125.

Eronat EGT, Bizsel KC. 2015. Diversity in Fish Fauna of Turkish Seas. DEVOTES-EUROMARINE Summer School "Marine ecosystem services, management and governance: linking social and ecological research" 9-11 June 2015- Aquarium of Donostia- San Sebastián, Spain.

Eronat EGT, Başusta N. 2018. Chondrichthyan species as bycatch: A review on species inhabiting Turkish waters. Journal of Black Sea/Mediterranean Environment, 24, (3): 288-305.

Filiz H, Mater S. 2002. A Preliminary Study on Length-Weight Relationships for Seven Elasmobranch Species from North Aegean Sea, Turkey. Ege Journal of Fisheries and Aquatic Sciences, 19(3-4), 401-409.

Filiz H, Bilge G. 2004. Length-weight relationships of 24 fish species from the North Aegean Sea, Turkey. J Appl Ichthyol, 20(3): 431-432. https://dx.doi.org/10.1111/j.14390426.2004.00582.x

Frisk MG, Miller TJ, Fogarty MJ. 2001. Estimation and analysis of biological parameters in elasmobranch fishes: a comparative life history study. Canadian Journal of Fisheries and Aquatic Sciences, 58: 969-981.
Froese R, Pauly D. 2020. Fish Base. http://www.fishbase.org (Accessed 05 January 2020).

Girgin H, Başusta N. 2016. Testing staining techniques to determine age and growth of Dasyatis pastinaca (Linnaeus, 1758) captured in Iskenderun Bay, northeastern Mediterranean. Journal of Applied Ichthyology, 32: 595-601.

Gurkan, S., Bayhan, B., Akcinar,SC. Taskavak, E. 2010. LengthWeight Relationship of Fish from Shallow Waters of Candarli Bay (North Aegean Sea, Turkey). Pakistan Journal of Zoology, 42(4): 495-498

Guven O, Kebapcioglu T, Deval MC. 2011. Length-weight relationships of sharks in Antalya Bay. Eastern Mediterranean. Journal of Zoology, 28, 278-279. https://dx.doi.org/10.1111/j.1439-0426.2011.01823.x

Hepkafadar O. 2008. İzmir Körfezi'nde Adi Köpekbalığ (Mustelus mustelus Linnaeus, 1758) Avc1lı̆̆1 ve Bazı Biyolojik Özellikleri Üzerine Araştırmalar (Master Thesis). Ege University, Izmir, Turkey

Hoenig JM, Gruber SH. 1990. Life-history patterns in the elasmobranchs: implications or fisheries management. In: Pratt HL Jr, Gruber SH, Taniuchi T (eds) Elasmobranchs as living resources: advances in the biology, ecology, systematics, and the status of fisheries. US Department of Commerce, NOAA Technical Report NMFS (National Marine Fisheries Service) 90, Washington, DC, p 1-16.

Ilkyaz AT, Metin G, Soykan O, Kinacigil HT. 2008. Lengthweight relationship of 62 fish species from the Central Aegean Sea, Turkey. Journal of Applied Ichthyology, 24, 699-702. https://dx.doi.org/10.1111/j.1439-0426.2008.01167.x

Ismen A. 2003. Age, growth, reproduction, and food of common stingray (Dasyatis pastinaca L., 1758) in İskenderun Bay, the eastern Mediterranean. Fisheries Research, 60: 169-176.

Ismen A, Ozen O, Altinagac U, Ozekinci U, Ayaz A. 2007. Weight-length relationships of 63 fish species in Saros Bay, Turkey. Journal of Applied Ichthyology, 23: 707-708. https://dx.doi.org/10.1111/j.1439-0426.2007.00872.x

Ismen A, Yigin CC, Altinagac U, Ayaz A. 2009. Length-weight relationships for ten shark species from Saros Bay (North Aegean Sea). Journal of Applied Ichthyology, 25, 109-112.

IUCN, 2021.The IUCN Red List of Threatened Species.

Karachle PK, Stergiou KI. 2012. Morphometrics and allometry in fishes. p. 65-86. In: Morphometrics. Wahl, C (Ed.). In Tech. Available from: http://www.intechopen.com/articles/ show/title/morphometrics-andallometry-in-fishes. ISBN: 978-953-51-0172-7

Karakulak FS, Erk H, Bilgin B. 2006. Length-weight relationships for 47 coastal fish species from the northern Aegean Sea, Turkey. Journal of Applied Ichthyology, 22(4), 274-278. https://dx.doi.org/10.1111/j.1439-0426.2006.00736.x

Kolher N, Casey J, Turner P. 1995. Length-weight relationships for 13 species of sharks from the western North Atlantic. Fish Bulletin, 93: 412-418.

Moutopoulos DK., Stergiou KI. 2002. Length-weight and length-length relationships of fish species from the Aegean Sea (Greece). Journal of Applied Ichthyology, 18: 200-203

Ozaydın O, Uckun D, Akalın S, Leblebici S, Tosunoglu Z. 2007. Length-weight relationships of fishes captured from Izmir Bay, Central Aegean Sea. Journal of Applied Ichthyology, 23(6), 695-696. http://dx.doi.org/10.1111/j.1439-0426.2007. 00853.x

Ricker WE. 1975. Computations and interpretation of biological statistics of fish populations. Fish Research Bd Canada Bull, 191: $382 \mathrm{pp}$.

Sakalli A, Yucel N, Capapé C. 2016. Confirmed occurrence in the Mediterranean Sea of Mobular japanica (Müller and Henle, 1841 ) with a first record off the Turkish coasts. Journal of Applied Ichthyology, 32(6): 1232-1234. 
Turker-Cakir D, Torcu-Koc H, Erdoğan Z. 2005. Some Biological Aspects of the Lesser Spotted Dog Fish Scyliorhinus canicula (Linnaeus, 1758) in Edremit Bay (The Northern Aegean Sea) Turkey. In N. Basusta, Ç. Keskin, F. Serena \& B. Seret (Eds.), The Proceedings ofthe International Workshop on Mediterranean Cartilaginous Fish with Emphasis on Southern-Eastern Mediterranean, (pp. 17-27) Istanbul, Turkey.

Türker D, Zengin K, Tunay ÖK. 2019. Length-Weigth Relationships for Nine Chondrichthyes Fish Species from Edremit Bay (North Aegean Sea). Turkish Journal of Fisheries and Aquatic Sciences, 19(1): 71-79.

Yeldan H, Avsar D. 2007. Length-weight relationship for five elasmobranch species from the Cilician Basin shelf waters (Northeastern Mediterranean). Journal of Applied Ichthyology, 23(6): 713-714.
Yeldan H, Avsar D, Manasırlı M. 2008. Kuzeydoğu Akdeniz'deki Deniz Tilkisi Raja clavata (Linnaeus, 1758)'nın Bazı Biyolojik Özellikleri. Ege Journal of Fisheries and Aquatic Sciences, 25(3): 221-228

Yeldan H, Avsar D, Manasırl1 M. 2009. Age, growth and feeding of the common stingray (Dasyatis pastinaca, L., 1758) in the Cilician coastal basin, northeastern Mediterranean Sea. Journal of Applied Ichthyology, 25(Suppl. 1) 98-102.

Yigin CC, Ismen A. 2009. Length-weight relationships for seven rays from Saros Bay (North Aegean Sea). Journal of Applied Ichthyology, 25 (Suppl. 1): 106-108. https://dx.doi.org/10.1111/j.1439-0426.2008.01161.x

Yücel N, Sakalli A, Karahan A. 2017. First record of the honeycomb stingray Himantura leoparda (ManjajiMatsumoto and Last, 2008) (Myliobatoidei: Dasyatidae) in the Mediterranean Sea, confirmed by DNA barcoding. Journal of Applied Ichthyology, 33(3): 530-532. https://www.resmigazete.gov.tr/ (erişim tarihi 19 Mayıs 2020) 